\title{
Analisis Fatwa DSN-MUI terhadap Kontrak Akad Qardh Di Lembaga Keuangan Syariah (Studi Kasus pada BPRS Baiturridha Pusaka)
}

\author{
Muhammad Yunus* \\ Fakultas Syariah Universitas Islam Bandung, Jl. Tamansari 24-26 Bandung \\ *Correspondence email: yunus_rambe @yahoo.co.id
}

\begin{abstract}
Abtsrak. Di Indonesia terdapat dua lembaga keuangan, yaitu lembaga keuangan konvensional dan lembaga keuangan syariah Lembaga keuangan syariah dalam operasionalnya berdasarkan pada fatwa yang telah dikeluarkan oleh Dewan Syariah Nasional Majelis Ulama Indonesia (DSN-MUI) sebagai lembaga yang memiliki otoritatif dalam mengeluarkan fatwa di bidang ekonomi syariah. Baiturridha Puska salah satu lembaga keuangan syariah mengeluarkan produk pembiayaan al-qardh. Dalam tataran praktiknya, yaitu yang dilaksanakan oleh BPRS Baituttidha Puska bahwa dalam kontrak tersebut terindikasi adanya klausula yang berbeda dengan ketentuan fatwa DSN-MUI No. 19 Tahun 2001 tentang al-Qardh. Tujuan penelitian ini untuk mengetahui konsep akad qardh dalam fikih dan fatwa DSN-MUI dan untuk mengalaisis kontrak akad pembiayaan qardh pada BPRS Baiturridha Pusaka. Penelitian ini menggunakan penelitian kualitatif, dengan pendekatan yuridis normatif dan teknik pengumpulan data dengan cara studi pustaka. Hasil penelitian menunjukan bahwa pertama, akad qardh merupakan bentuk akad tabarru sehingga tidak diperuntukan untuk mencari keuntungan; kedua, ketentuan Pasal 2 Surat Pengakuan Pembiayaan terdapat klausula yang bertentangan dengan prinsip syariah, yaitu fatwa DSN-MUI No. 19 Tahun 2001 tentang al-Qardh.
\end{abstract}

Kata Kunci: Fatwa DSN-MUI; Qardh; Perbankan Syariah

Abstract. In Indonesia, there are two financial institutions, namely conventional financial institutions and Islamic financial institutions. Islamic financial institutions in their operations are based on the fatwa that has been issued by the National Sharia Council of the Indonesian Ulema Council (DSN-MUI) as an authoritative institution in issuing fatwas in the field of Islamic economics. Baiturridha Puska, one of the Islamic financial institutions, issued al-qardh financing products. At the level of practice, which is implemented by BPRS Baituttidha Puska that in the contract it is indicated that there is a clause that is different from the provisions of the DSN-MUI fatwa No. 19 of 2001 concerning al-Qardh. The purpose of this study was to determine the concept of the qardh contract in figh and the DSN-MUI fatwa and to analyze the qardh financing contract contract at the Baiturridha Pusaka BPRS. This study uses qualitative research, with a normative juridical approach and data collection techniques by means of literature study. The results of the study show that first, the qardh contract is a form of tabarru contract so it is not intended for profit; secondly, the provisions of Article 2 of the Letter of Acknowledgment of Financing contain a clause that is contrary to sharia principles, namely the DSN-MUI fatwa no. 19 of 2001 concerning al-Qardh.

Keywords: DSN-MUI Fatwa; Qardh; Sharia Banking

\section{PENDAHULUAN}

Perkembangan praktik Lembaga Keuangan Syariah (LKS) baik di level nasional maupun internasional telah memberikan gambaran bahwa sistem ekonomi Islam dapat beradaptasi dengan perekonomian konvensional yang telah lama menguasai kehidupan masyarakat dunia maupun di Indonesia. Dengan perkembangan tumbuh dan berkembangnya LKS dapat membuktikan bahwa masyarakat menganggap penting bertransaksi dengan prinsip syariah. (Ash-Shiddiqy, 2018)

Pasal 1 angka 12 Undang-Undang No. 21 Tahun 2008 tentang Perbankan Syariah yang merupakan payung/reguasi perbankan syariah di Indonesia memberikan pengertian prinsip syariah sebagai prinsip hukum Islam dalam kegiatan perbankan berdasarkan fatwa yang dikeluarkan oleh lembaga yang memiliki kewenangan dalam penetapan fatwa di bidang Syariah

Lembaga Keuangan Syariah (LKS) termasuk di dalamnya Bank Syariah memiliki tanggung jawab dalam melaksanakan kegiatan usahanya sebagaimana ketentuan UUPS bahwa menjalankan prinsip syariah dalam kegiatan usahanya, dalam konteks Indonesia impelmentasi prinsip syariah terwujud dalam fatwa Dewan Syariah Nasional Majelis Ulama Indonesia (DSN-MUI). (Dewi, 2020)

Bagi Lembaga Keuangan Syariah di Indonesia termasuk di dalamnya Bank Syariah fatwa Dewan Syariah Nasional-Majelis Ulama Indonesia (DSN-MU) selain sebagai pedoman berfungsi sebagai legitimasi. Artinya setiap produk yang dikeluarkan oleh LKS harus sesuai dengan ketentuan fatwa DSN-MUI. Hal itu sebagaimana nilai dan moralitas serta keinginan dari para pelaku aktivitas ekonomi syariah. Karena merekalah yang mejalankan sistem operasional lembaga keuangan syariah. Sehingga mereka memiliki tanggungjawab yang besar untuk mengelola Lembaga keuangan syariah yang sistem operasional bisnis maupun produk yang ditawarkannya harus sesuai dengan ketentuan syariah. Adapun otoritas yang memiliki 
kewenangan dalam melakukan penilaian dan penetapan bahwa suatu produk sudah sesuai prinsip dan nilai-nilai syariah adalah DSN-MUI. (Izazi dan Ayu, 2021)

Sebagai otoritas yang mengeluarkan aturan sebagai rujukan oleh setiap lembaga keuangan syariah (LKS) di Indonesia, DSN-MUI telah melakukan upaya besar dalam memberikan legalitas hukum sebagai bahan untuk pengawasan ditingkat dewan pengawas syariah. Berdasarkan aturan yang mengatur lembaga keuangan syariah terutama perbankan syariah berdasarkan amanah Undang-Undang No 21 tahun 2008 tentang Perbankan Syariah, maka setiap perbankan syariah yang menjalankan aktifiatas bisnis harus mendapatkan legalitas formal dalam bentuk fatwa dari DSN-MUI. (Febrian, 2020)

Sebagai lembaga intermediary finance yang mengimplementasikan nilai-nilai syariah dalam operasionalnya, maka lembaga keuangan syariah (LKS) menggunakan akad-akad yang tertuang dalam kajian fikih Islam serta mengelaborasinya dengan konsep keuangan modern baik lembaga bank maupun non bank (Wiwik, 2015)

Pertumbuhan Lembaga Keuangan Syariah salah satunya ditandai dengan munculnya produk-produk kreatif yang ditawarkan kepada masyarakat. Penawaran produk-produk baru tersebut sebagai salah satu strategi pemasaran untuk meningkatkan nasabah di tengah persaingan LKS yang semakin terbuka. Munculnya produk-produk baru di LKS menimbulkan kesulitan penerapan prinsip syariah terutama pada aspek kesesuaiannya dengan kontrak (akad). Semakin modernnya dunia bisnis dengan produknya yang baru akan memicu persoalan keabsahan kegiatan keuangan itu (Maksum, 2014)

Dalam akad-akad produk lembaga keuangan syariah apabila ditinjau dari segi untuk mendapat kompensasi atau tidak mendapat kompensasi, maka dapat dibedakan menjadi dua jenis yaitu akad tabarru dan akad tijarah/mu'awadah. Akad tabarru' adalah segala macam perjanjian yang menyangkut not-for profit (transaksi nirlaba). Transaksi ini pada hakikatnya bukan transaksi bisnis untuk mencari keuntungan komersil. Akad tabarru' dilakukan dengan tujuan tolongmenolong dalam rangka berbuat kebaikan. Pada hakikatnya, akad tabarru' adalah akad melakukan kebaikan yang mengharapkan balasan dari Allah SWT semata, itu sebabnya akad ini tidak bertujuan mencari keuntungan komersil (Ilda Hayati, 2016)

Pada saat ini, Produk Pembiayaan yang dilaksanakan oleh BPRS Baiturradha Puska secara garis besar meliputi: Murabahah, Mudharabah, dan Qardh (pinjam kebajikan). Namun, pelaksanaan akad qardh yang domainnya masuk dalam ranah akad tabarru' sebagaimana penulis uraikan di atas, dalam pelaksanaannya sebagaimana tertera dalam salah satu kontrak perjanjian akad qardh teridentifikasi adanya klausula yang belum memenuhi prinsip syariah. Oleh karena itu perlu dilakukan analisi dalam penelitian ini guna memberikan kepastian hukum terkait keabsahan kontrak perjanjian akad qardh yang dilakukan di Lembaga Keuangan Syariah salah satunya Bank Pembiayaan Rakyat Syariah (BPRS) Baiturradha Puska.

\section{METODE}

Penelitian ini menggunakan metode penelitian kualitatif dengan pendekatan yuridis normatif, di mana peneliti menelaah teori, konsep, ataupun asas hukum yang berhubungan akad qardh. Sumber data primer yang digunakan dalam penelitian ini diambil fatwa-fatwa DSN-MUI. Adapun sumber sekunder dalam penelitian ini adalah kitab-kitab fikih serta artikel-artikel dalam jurnal, serta buku-buku rujukan yang relevan dan berkaitan dengan penelitian. Teknik pengumpulan data dilakukan dengan cara liblary study atau studi pustaka. Setelah data yang diperlukan terkumpul, maka langkah selanjutnya adalah mengolah dan menganalisis data tersebut serta diambil kesimpulan hukum.

\section{HASIL DAN PEMBAHASAN \\ Akad Qardh dalam Literatur Fikih Muamalah}

Kata qaradh merupakan bahasa Arab yang secara harfiah kata qardh merupakan bentuk masdhar dari kata qaradha asy-syai'-yaqridhu, yang berarti dia memutuskannya. Qardh adalah bentuk masdhar yang berarti memutuskan. Dikatakan, qaradhu sya'ia bilmiqradh atau memutus sesuatu dengan gunting. Alqardh adalah sesuatu yang diberikan oleh pemilik untuk dibayar (Panji Adam, 2017).

Pengentian akad qardh secara istilah dalam terminologi para ahli fikih di antaranya adalah sebagai berikut

Ibn 'Abidin salah seorang ulama dari mazhab Hanafi menyampaikan yang maksud dengan akad qardh adalah:

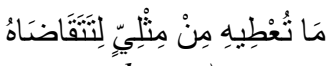

"Sesuatu yang diberikan (berupa harta) yang terdapat padanannya (di pasaran) untuk dikembalikan kembali (harta tersebut)". (Abidin, 1992)

Abu Bakar salah seorang ulama dari mazhab Maliki memberikan definisi akad qardh sebagai berikut:

$$
\text { إعطاء متمول في عوض مماتل في الذمة لنفع المعطي فقط }
$$

"Memberikan harta yang memiliki nilai manfaat dengan (kewajiban) memberikan ganti dengan harta yang sepadan yang berada dalam tanggung jawabnya (pihak peminjam) untuk diambil manfaatnya saja” (Bakar n.d.)

Khatib Syarbini yang merupakan ulama Syafi'iyyah dalam kitabnya Mughnî al-Muhtâj memberikan definisi akad qardh yaitu 


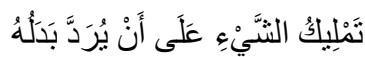 \\ "Perpindahan kepemilikan atas benda untuk \\ dikembalikan dengan harta yang sepadan"” (Al- \\ Syarbini, 1994)
}

Adapun ulama dari mazhab Hanbali yaitu alBahuti dalam kitab Muntaha al-Iradat memberikan definisi akad qardh sebagai berikut:

$$
\text { دفع مالٍ إرفاقاً لمن بنتفع به ويردّ بدلَه }
$$

"Menyerahkan harta dengan tujuan menolong untuk dimanfaatkan (oleh pihak peminjam) serta wajib untuk mengembalikan harta tersebut dengan yang sepadan" (Ibn Najjar, 1999)

Keabsahan akad qardh dalam Islam didiasarkan pada ayat al-Quran, hadis Nabawi serta ijmâ ulama. Di dalam al-Quran surah al-Baqarah (2): 245 dan surah alHadid (57): 11 merupakan landasan syar'i mengenai keabsahan akad qardh. Adapun ketentuan syar'i akad qaradh dalam hadis Nabawi sebagaimana tertera dalam kitab Sunan Ibn bahwasannya Rasulullah Saw bersabda:

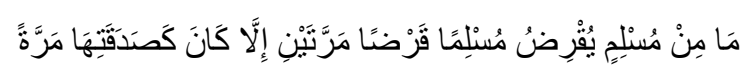

"Tidaklah seorang muslim yang memberikan pinjaman kepada muslim lainnya sebanyak dua kali, kecuali laksana melakukan satu kali sedekah" (Ibn Majah, 2008)

Landasan yuridis akad qardh berdasarkan ijmak sebagaimana dikemukakan oleh Wahbah al-Zuhaili bahwa para ulama telah sepakat (ijmak) tentang bolehnya melakukan akad qardh karena adanya kebutuhan (al-hajjah) untuk melakukannya dan termasuk dari bagian ta'awun (saling tolong-menolong) dalam kebaikan serta ketakwaan sebagaimana termaktub dalam al-Quran surah al-Maidah (5): 2; dan sah dilakukan dengan cara ijab dan kabul (akad) (Wahbah al-Zuhaili, 2002).

Ulama sepakat bahwa dalam akad harus terdapat komponen akad atau biasa disebut dengan istilah rukun akad, meskipun secara teoritis para ulama berbeda pendapat tentang rukun akad. Menurut ulama dari kalangan Hanafiyyah, rukun akad hanya satu, yaitu pernyataan penawaran dan persetujuan (shighat ijab dan qabul). Adapun dalam pandangan mayoritas ulama fikih, bahwa para pihak yang berakad dan objek akad merupakan rukun/komponen akad. Bahkan terdapat pendapat yang menyatakan bahwa muqtadha al-'aqd (karakteristik akad) sebagai rukun akad. Oleh karena itu, yang termasuk rukun akad sebagaimana dismapaikan oleh Wahbah al-Zuhaili ada 4 (empat), yaitu: pertama, Muqridh ( $d a^{\prime}$ in), yaitu pihak yang memberi pinjam harta atau yang memiliki piutang (hak tagih); keduam, Muqtaridh (madin), yaitu pihak yang menerima pinjaman harta atau pihak yang memiliki utang (wajib bayar); ketiga, al-Qardh (al-ma'qud 'alaih), yaitu objek/harta yang dipinjamkan yang wajib untuk dikembalikan padanannya kepada muqridh (pemilik harta/pemilik piutang); dan keempat, shighat, yaitu pernyataan ijab dan kabul (Wahbah al-Zuhaili, 2002)

\section{Akad Qardh dalam Fatwa Dewan Syariah Nasional- Majelis Ulama Indonesia (DSN-MUI)}

Dalam konteks Indonesia, akad qardh telah dipraktikkan oleh Lembaga Keuangan Syariah (LKS) baik lembaga bank maupun non bank, yang didasarkan pada fatwa DSN-MUI Nomor 19 Tahun 2001 tentang alQardh.

Ketentuan yang terdapat dalam Fatwa DSN-MUI Nomor 19/DSN-MUI/IV/2001 terdiri atas 3 (tiga) bagian, antara lain:

1. Ketentuan umum tantang $a l$-qardh:

a. Al-Qardh adalah pinjaman yang diberikan kepada nasbaah (muqtaridh) yang memerlukan.

b. Nasabah al-qardh wajib mengembalikan jumlah pokok yang diterima pada waktu yang telah disepati bersama.

c. Biaya administrasi dibebankan kepada nasabah.

d. Lembaga Keuangan Syariah dapat meminta jaminan kepada nasabah bilama dipandang perlu.

e. Nasabah al-qardh dapat memberikan tambahan (sumbangan) dengan sukarela kepada Lembaga Keuangan Syariah selama tidak diperjanjikan dalam akad.

f. Jika nasabah tidak dapat mengembalikan sebagian atau seluruh kewajiban pada saat yang telah disepakati dan Lembaga Keuangan Syariah telah memastikan ketidakmampuannya, Lembaga Keuangan Syariah dapat memperpanjang jangka waktu pengembalian atau menghapus (write off) sebagian atau seluruh kewajibannya.

2. Ketentuan mengenai sanksi:

a. Dalam hal nasabah tidak menunjukkan keinginan mengembalikan sebagaian atau seluruh kewajibannya dan bukan karena ketidakmampuannya, Lembaga Keuangan Syariah dapat menjatuhkan sanksi kepada nasabah.

b. Sanksi yang dijatuhkan kepada nasbaah, sebagaimana dimaksud, dapat berupa penjualan barang jaminan.

c. Jika barang jaminan tidak mencukupi, nasabah tetap harus memenuhi kewajibannya secara penuh.

3. Ketentuan mengenai sumber dana:

a. Bagian modal Lembaga Keuangan Syariah.

b. Keuntungan Lembaga Keuangan Syariah yang disisihkan.

c. Lembaga lain atau individu yang mempercayakan penyaluran infaknya kepada Lembaga Keuangan Syariah.

Di samping fatwa khsuus tentang qardh yang kemudian tesebar ke dalam 16 (enam belas) fatwa yang di dalamnya terdapat akad qardh, terdapat fatwa unik 
yang berkaitan dengan qradh, yaitu fatwa DSN-MUI Nomor 79 Tahun 2011 tentang Qardh dengan Menggunakan Dana Nasabah. Dalam fatwa tersebut diatur dan dijelaskan mengenai ragam penggunaan akad qardh dalam produk Lembaga Keuangan Syariah, antara lain: (Hasanudin, 2017)

1. Akad qardh yang berdiri sendiri untuk tujuan sosial semata, sebagaimana dimaksud dalam fatwa DSNMUI Nomor 19 Tahun 2001 tentang al-Qardh, bukan sebagai saraa atau kelengkapan bagi transaksi lain dalam produk yang bertujuan untuk mendapatkan keuntungan.

2. Akad qardh yang dilakukan sebagai sarana atau kelengkapan bagi transkasi lain yang menggunakan akad-akad mu'awadhat (pertukaran dan dapat bersifat komersial) dalam produk yang bertujuan untuk mendapatkan keuntungan, sebagaimana terdapat dalam seumlah fatwa DSN-MUI.

Substansi dan ketentuan hukum fatwa DSN-MUI Nomor 79 Tahun 2011 tentang Qardh dengan Menggunakan Dana Nasabah adalah:

1. Akad qardh yang berdiri sendiri untuk tujuan sosial semata tidak boleh menggunakan dana nasabah.

2. Akad qardh yang dilakukan sebagai sarana atau kelengkapan bagi transaksi lain yang menggunakan akad-akad mu'awadhah (pertukatan dan dapat bersifat komersial) dalam produk yang bertujuan untuk mendapatkan keuntungan, boleh menggunakan dana nasabah.

3. Keuntungan atau pendapat dari akad atau produk yang menggunakan mu'awadhah yang dilengkapi dengan akad qardh harus dibagikan kepada nasabah penyimpan dana sesuai akad yang dilakukan.

\section{Akad Qardh dalam Qanun (Regulasi) di Indonesia}

Akad qardh termasuk akad yang aktual karena eksistensinya melekat pada Lembaga Keuangan Syariah, terutama perbankan syariah. Dalam Undang-Undang Nomor 21 Tahun 2008 tentang Perbankan Syariah, terdapat 3 (tiga) ketentuan mengenai akad qardh, antara lain:(Hasanudin, 2017)

1. Pada Pasal 1 angka 20 dinyatakan bahwa simpanan adalah dana yang dipercayakan oleh nasabah kepada bank syariah dan/atau unit usaha syariah berdasarkan akad wadi'ah atau akad lain yang tidak bertentangan dengan prinsip syariah dalam bentuk giro, tabungan, atau bentuk lainnya yang dipersamakan dengan itu.

2. Pada Pasal 1 angka 5 dinyatakan bahwa pembiayaan adalah penyediaan dana atau tagihan yang dipersamakan dengan itu berupa:

a. Transaksi bagi hasil dalam bentuk mudharabah dan musyarakah.

b. Transaksi sewa-menyewa dalam bentuk ijarah atau sewa beli dalam bentuk ijarah muntahiya bittamlik. c. Transaksi jual-beli dalam bentuk piutang murabahah, salam dan istishna'.

d. Transaksi pinjam-meminjam dalam bentuk piutang qardh.

e. Transaksi sewa-menyewa jasa dalam bentuk ijarah untuk transaksi multijasa berdasarkan persetujuan atau kesepakatan antara bank syariah dan/atau unit usaja syariah dan pihak lain yang mewajibkan pihak yang dibiayai dan/atau diberi fasilitas dana untuk mengembalikan dana tersebut setelah jangka waktu tertentu dengan imbalan ujrah, tanpa imbalan, atau bagi hasil.

Dalam Undang-Undang Nomor 21 Tahun 2008 tentang Perbankan Syariah terlihat bahwa akad qardh digunakan dalam rangka penyaluran dana atau pembiayaan (financing/lending).

\section{Analisis Fatwa Dsn-Mui Terhadap Kontrak Akad Qardh Di Lembaga Keuangan Syariah (Studi Kasus Pada BPRS Baiturridha Pusaka)}

Sebagaiamana telah disinggung di atas bahwa para ulama merumuskan secara garis besar akad dibagi menjadi 2 (dua), yaitu akad mu'awadhah (akad pertukaran/komersil) dan akad tabarru' (akad sosial). Akad qardh oleh para fukaha dikategorikan sebagai akad tabarru' artinya sejak awal akad ini dibangun dengan dasar saling tolong-menolong dan bukan berfungsi sebagai akad komersial. Dalam akad qardh, para ulama membuat parameter (dhawabit) mengenai syarat dan larangan. Secara umum, parameter tersebut menyangkut 3 (tiga) hal, yaitu harta yang dijadikan objek akad qardh, personalia akad (muqridh) dan sifat akad qardh. Adapun uraian mengenai dhawabit akad qardh tersebut sebagaimana diterangkan oleh Wahbah al-Zuhauli sebagai berikut:(Wahbah al-Zuhaili, 2002)

1. Ketentuan dan syarat harta qardh dari segi kepemilikan berlaku ketentuan dan syarat al-mabi' (benda yang menjadi objek dalam akad jual-beli), yaitu harta yang di-qardh-kan harus milik muqridh karena sifat al-tamlik-nya sama, yaitu harta qardh berpindah kepemilikannya dari milik muqridh menjadi milik muqtaridh sehingga muqridh harus memiliki hak untuk memindahkan kepemilikan barang (intiqal al-milikyyah) barang yang di-qardhkan.

2. Harta yang boleh dijadikan objek akad qardh harus harta yang mitsliyyat (ada padanannya) yang disepakati ukurannya, baik secara kuantitas (takaran, timbangan, jumlah atau ukuran yang disepakati bedasarkan kebiasaan bisnis) maupun kualitasnya.

3. Personalia akad (muqridh) harus termasuk pihak yang memiliki kemampuan untuk melakukan tabarru' karena akad qardh termasuk akad yang menyebabkan terjadinya perpindahan kepemilikan objek akad tanpa disertai iwadh (imblan/kompensasi). 
4. Penguasaan (al-qabdh); akad qardh tidak sempurna, kecuali objek akad-nya dipindahkan penguasaanya dari muqridh kepada muqtaridh karena al-qardh merupakan bagian dari akad tabarru' yang tidak sah akadnya, kecuali setelah objeknya dikaasi muqtaridh.

5. Pengambilan manfaat qrdh; muqridh tidak boleh mengambil manfaat atas akad al-qardh yang dilakukannya, baik manfaat tersebut diperjanjikan atau disepakati dalam akad maupun telah menjadi kebiasan yang dianggap baik. Di antara pengambilan manfaat qradh adalah iwadh (imbalan/kompensasi), baik berupa barang maupun jasa.

Beberapa diskusi mengenai imbalan atas qardh, antara lain:

a. Imbalan atas qardh boeh diterima muqridh dengan ketentuan bahwa imbalan tersebut tidak diperjanjikan dalam akad karea adanya hadis yang berbunyi:

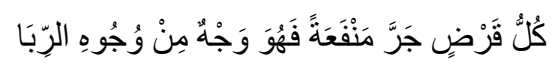

"Setiap pinjaman yang mengambil manfaat maka termasuk riba"(al-Baihaqi, 1989)

b. Imbalan qardh tidak boleh menjadi kebiasaan karena adanya kaidah fikih yang berbunyi:

$$
\text { الْمَرُوْ عرفا كالمشروطشرط }
$$

"Perbuatan yang dianggap baik berdasarkan kultur, maka hal tersebut bagaiman syarat yang berlaku diantara mereka" (al-Zarqa, 2012)

Berberda kondisinya apabila manfaat atau imbalan itu tanpa dipersyaratkan di awal akad, yang mana pihak muqtaridh memberikan imbalan disertai manfaat kepada muqridh tanpa disyaratkan atau diperjanjikan serta tidak menjadi suatu kebiasaan maka itu termasuk konsep qardh hasan sekaligus etika dalam hutang-piutang dalam Islam. Hal ini sebagaimana keterangan hadis berikut:

$$
\text { وَخَيَرْكُمْ أَحْنَنُكُمْ قَضَنَاءً }
$$

"Orang terbaik di antara kalian adalah orang yang memberikan imbalan pada saat membayar utang" (Muslim n.d.)

c. Pengkombinasian antara akad qardh dan akad bai' (jual-beli) merupakan transaksi yang terlarang. Hal ini sebagaimana sabda dari Rasulullah Saw megenai larangan menggabungkan akad qardh dengan akad jual-beli sebagai berikut:

$$
\text { لَا يَحِلُ سََلَفْ وَبَيْعُ }
$$

"menggabungkan akad hutang dengan jual-beli adalah tidak halal (terlarang)". (Abu Dawud, 2007)

Bank Pembiayaan Rakyat Syariah (BPRS) Baiturridha Pusaka merupakan salah satu Lembaga
Keuangan Syariah yang menjalankan kegiatan usahanya berdasarkan prinsip syariah. Salah satu jenis pembiayaan yang dipraktikan oleh BPRS Baiturridha Pusaka adalah Akad Pembiayaan Al-Qardh. Salah satu kontrak pembiayaan al-Qardh pada BPRS Baiturridha Pusaka yaitu Akad Pembiayaan al-Qardh dengan nomor kontrak 010/PBR-QARDH/XI/2020 yang kontrak tersebut dibuat pada tanggal 10 November 2020 yang ditandatangani oleh para pihak di antaranya BPRS Baiturridha Pusaka dan Nasabah.

Pada Pasal 2 kontrak tersebut dijelaskan bahwa Bank memberikan pinjaman uang dan oleh karena itu berhak menagih kepada Nasabah sejumlah utang yang belum dibayar oleh Nasabah, dan Nasabah menerima pinjaman uang dan oleh karena itu mengaku berutang dan berjanji akan membayar kembali kepada Bank yang jumlahnya akan disebutkan pada Pasal 3 Akad ini dalam jangka waktu dan cara dan tempat pembayaran sebagaimana yang ditetapkan Pasal 6 Akad ini.

Adapun Pasal 3 kontrak berkiatan dengan Jumlah Pinjaman yang mengandung 2 hal: pertama, pinjaman sebagaimana dimaksud pada Pasal 2 tersebut di atas adalah sebesar Rp. 64.000.000 (Enampuluh Empat Juta Rupiah) dan Akad ini berlaku pula sebagai tanda terimanya; kedua, besaran pinjaman sebagaimana ayat 1 Pasal ini belum termasuk biaya-biaya yang timbul sehubungan dengan Akad ini.

Sekilas pada kedua pasal di atas baik pada Pasal 2 maupun Pasal 3 terlihat tidak terdapat adanya problem hukum berupa ketidak sesuaikan dengan prinsip syariah. Akan tetapi, penulis mengamati dalam "Surat Pengakuan Pembiyaan" kontak atau akad ini, khususnya Pasal 2 terdapat bunyi pasal sebagai berikut:

\begin{abstract}
"Adapun pembiayaan itu besama-sama pokok sebesar Rp. 64.000.000 (Enam Puluh Empat Juta Rupiah) Harus dibayar kembali oleh Yang memiliki pembiayaan kepada Bank menurut angsuran yang sama besarnya atau sesuai tabel angsuran pokok dan bagi hasil/margin yang berlaku pada pembiayaan ini dalam 2 (dua) kali angsuran setiap haril minggu/ bulan dan melunasi pada saat jatuh tempo sebesar Rp. 64.000 .000 (Enam Puluh Empat Juta Rupiah) dimulai sejak tanggal 10 Desember tiap-tiap bulan sebelum atau selambat-lambatnya pada tangga; 24 Setiap bulan dan pokok pembiayaan akan dikembalikan pada saat jatuh tempo atau pada tanggal 10 Januari 2021".
\end{abstract}

Pada Pasal 2 Surat Pengakuan Pembiayaan di atas terlihat adanya ketentuan bahwa Nasaah diharuskan membayar kepada pihak Bank menurut angsuran yang sama besarannya atau sesuai tabel angsuran pokok dan "bagi hasil/margin" yang berlaku pada pembiayaan ini. Hal tentunya menarik untuk dikaji serta dilakukan analisis berdasarkan fatwa Dewan Syariah NasionalMajelis Ulama Indonesia (DSN-MUI) yang merupakan 
ketentuan regulasi di Indonesia sebagai bentuk kepatuhan terhadap prinsip syariah.

Dewan Syariah Nasional adalah lembaga fatwa yang telah menerbitkan banyak fatwa terkait transaksi ekonomi syariah di Indonesia. hal ini dapat dikatakan sebagai perkembangan yang progresif dalam rangka melahirkan inovasi dan terobosan produk akad muamalat di era kontemporer (Adam, 2017). Salah satu produk fatwa DSN-MUI adalah fatwa Nomor 19/DSNMUI/IV/2001 tentang al-Qradh. Sebagaimana telah penulis uraikan di atas bahwa akad qardh merupakan salah satu bagian dari akad tabarru', artinya sejak awal akad ini berfungsi sebagai ta'awun atau tolong-meolong dan akad sosial, sehingga akad ini tidak bertujuan untuk mencari profit atau keuntungan.

Dalam ketentuan fatwa DSN-MUI No. 19 tentang al-Qradh dijelaskan bahwa Al-Qardh adalah pinjaman yang diberikan kepada nasbaah (muqtaridh) yang memerlukan dan Nasabah al-qardh wajib mengembalikan jumlah pokok yang diterima pada waktu yang telah disepati bersama. Ketentuan fatwa ini menjelaskan bahwa nasabah hanya wajib mengembalikan jumlah pokok yang diterima pada waktu yang telah disepakati bersama. Oleh karenanya kedudukan akad qardh merupakan akad tabarru' yang tidak bertujuan untuk mencari profit/keuntungan.

Akan tetapi, pada Pasal 2 Surat Pengakuan Pembiayaan di atas terlihat adanya ketentuan bahwa Nasaah diharuskan membayar kepada pihak Bank menurut angsuran yang sama besarannya atau sesuai tabel angsuran pokok dan "bagi hasil/margin". Istilah bagi hasi identik dengan akad kerja-sama baik mudharabah ataupun musyarakah yang merupakan akad yang bertujuan untuk mencari keuntungan. Dengan demikian ketentuan Pasal 2 Surat Pengakuan Pembiayaan kontrak BPRS Baiturridho Pusaka menurut hemat penulis bertentangan dengan ketentuan fatwa DSN-MUI No. 19 yang menentukan bahwa dalam akad qardh nasabah hanya diwajibkan mengembalikan harta pokok pinjaman tanpa diserta bagi hasil/margin. Oleh karenanya bunyi Pasal 2 Surat Pengakuan Pembiayaan tersebut perlu direvisi sehingga pasal tersebut sesuai dengan prinsip syariah.

Implikasi hukum terhadap akad dalam perspektif fikih muamalah bahwa akad qardh yang menarik manfaat dikhawatirkan akan terjerumus terhadap praktik ribawi yang dilarangan secara syariah. Salah satu mamfaat di sini adalah seperti margin ataupun bagi hasil yang meurpakan konsep dari akad mu'awadhah.

Sebagaimana penulis diuarikan di atas mengenai dhawabith atau parameter akad qardh yang disusun oleh para ulama bahwa salah satu parameter terpenting dalam akad qardh adalah muqridh (dalam hal ini Bank) tidak boleh mengambil manfaat atas akad al-qardh yang dilakukannya, baik manfaat tersebut diperjanjikan atau disepakati dalam akad maupun telah menjadi kebiasan yang dianggap baik. Di antara pengambilan manfaat qradh adalah iwadh (imbalan/kompensasi), baik berupa barang maupun jasa. Pengambilan manfaat pada akad qardh ini merupakan betuk riba qardh.

Secara sederhana dapat dikatakan bahwa Suatu manfaat atau tingkat kelebihan tertentu yang disyaratkan terhadap yang berhutang (muqtaridh) (Adam, 2017). Jumhur ulama berpendapat bahwa riba qardh merupakan bagian dari riba jahiliyah yang diharamkan dalam alQuran, dan dalam riba qardh terkandung riba fadhl. Oleh karena itu, jika tambahan dalam riba jahiliyah terhadi karena yang beutang tidak dapat melunasi utangnya tepat waktu sesuai kesepakatan (riba terjadi karena kompensasi atas gagalnya pelunasan utang), riba qardh lebih haram daripada riba jahiliah terjadi pada saat addendum akad. Sedangkan riba qardh terjadi pada akad qardh dilakukan (istilah yang digunakan adalah $\min b a b$ al-awla; atau qiyas awlawi dalam pandangan ulama Syafi'iyyah) (Hasanudin, 2017b)

Terdapat beberapa kaidah fikih yang relavan berkaitan dengan riba qardh bahkan menjadi landasan yuridis fatwa DSN-MUI dalam penetapan fatwa terkait dengan al-Qardh. Adapun kaidah-kaidah fikih tersebut adalah sebagai berikut:

$$
\text { كل قرض اشتر اط فيه المفع مقدما فهو ربا }
$$

"Pinjaman yang disyaratkan adanya bunga di awal transaksi adalah riba" (Ramdhan, 2007)

Kaidah di atas dapat dipahami, bahwa setiap utang piutang yang diberikan harus dibayar sesuai jumlah nominal yang diterima pihak yang berutang. Jika akad utang yang dipersyaratkan di muka dengan kewajiban membayar lenih dari utangnya, maka ini termasuk praktik riba. Oleh sebab itu, setiap utang (qardh) yang dipersyaratkan adanya manfaat lebih kepada pemberi utang di awal akad maka ini termasuk riba (Moh. Mufid, 2019).

Kaidah lainnya yang serupa dengan kaidah di atas adalah sebagai berikut:

$$
\text { كلّ قرض شرط فيه أن يزيده فهو حر ام بغير خلاف }
$$

"Setiap utang-piutang yang disyaratkan di dalanya adanya tambahan, maka hal itu diharamkan tanpa adanya perbedaan" (Muhammad Shodiqi Ibn Ahmad Ibn Muhammad al-Buruni Abu al-Harits al-Ghazi, 2003)

$$
\text { كُلْ قَرِْْ جَرَّ نَفْعَا حَرَامُ }
$$

"Setiap utang-piutang yang menarik manfaat adalah diharamkan" (Ibn Nujaim, 1999)

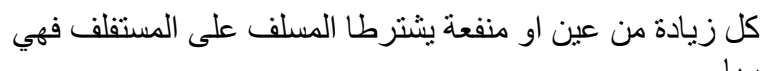

"Setiap tambahan benda atau manfaat yang disyaratkan oleh pemberi pinjam kepada peminjam adalah riba" (Hidayat, 2019) 
Ketiga kaidah di atas menjelaskan bahwa terkiat utang-piutang yang di dalamnya adanya tambahan yang dipersyaratkan oleh pemberi pinjam kepada peminjam, meskipun disetujui oleh peminjam, maka hal tersebut tergolong ke dalam riba. Hal ini berbeda jika tidak disyaratkan sebelumnya oleh pemberi pinjam, melainkan hanya keridhoan pihak peminjam karena jasa yang telah diberikan pemberi pinjam. Maka, hal tersebut tidak tergolong riba. Tidak ada pertentangan di antara para ulama mengenai masalah tersebut. dengan demikian, dapat dikatakan bahwa telah terjadi ijmak/konsensus di kalangan para ulama.

Berdasarkan keterangan fatwa DSN-MUI No. 19 tentang al-Qardh serta kaidah-kaidah fikih di atas, maka menurut hemat penulis ketentuan bunyi Pasal 2 Surat Pengakuan Pembiayaan bahwa pihak Nasabah diharuskan membayar kepada pihak Bank menurut angsuran yang sama besarannya atau sesuai tabel angsuran pokok dan "bagi hasil/margin" yang berlaku pada pembiayaan ini, merupakan ketentuan pasal yang tidak sesuai dengan prinsip syariah, bahkan berpotensi melahirkan hukum riba qardh, hal ini dikaternakan akad utang-piutang yang melahirkan manfaat (margin/bagihasil) maka termasuk riba qradh. Oleh karenanya, ketentuan Pasal 2 tersebut perlu diperbaiki sesuai dengan ketentuan serta prinsip syariah pada aka qardh.

\section{SIMPULAN}

Akad qardh adalah perpindahan kepemilikan barang kepada pihak lain yang wajib dikembalikan (oleh peminjam) tanpa imbalan. Akad ini tergolong kedalam akad tabarru' artinya akad tersebut bertujuan untuk tolong-menolong dan tidak bertujuan untuk mencari keuntungan. Dalam praktiknya akad qardh diterapkan dalam produk pembiayaan bank syariah salah satunya yang dipraktikan oleh BPRS Baiturridho Puska. Namun berdasarkan analisis penulis terhadap kontrak tersebut ditemukan pada Pasal 2 Surat Pengakuan Pembiayaan kontrak/akad tersebut terdapat klausa bahwa nasabah diharuskan membayar pokok sesuai dengan tabel angsuran pokok bagi hasil/margi. Oleh karenanya ketentuan tersebut adanya kesenjangan atau ketidaksesuaian dengan prinsip syariah, yaitu fatwa DSN-MUI No. 19 Tahun 2001 yang menyatakan bahwa nasabah diwajibkan hanya mengembalikan jumlah pokok.

\section{DAFTAR PUSTAKA}

Abidin, Ibn. 1992. Rad Al-Mukhtar 'ala Al-Dar AlMukhtar. Beirut: Dar al-Fikr.

Abu Dawud. 2007. Sunan Abî Dâwud. Beirut: Dâr alFikr.

Adam, Panji. 2017. Fatwa-Fatwa Ekonomi Syariah: Konsep, Metodologi Dan Implementasinya Pada Lembaga Keuangan Syariah. Jakarta: Amzah. . 2019. Fikih Muamalah Adabiyah. Bandung: Refika Aditama.
al-Baihaqi. 1989. Al-Sunan Al-Kubrâ. Beirut: Dar alKutub al-'Ilmiyyah.

Al-Syarbini, Khatib. 1994. Mughni Al-Muhtaj Ila Ma'rifah Ma'ani Al-Fadz Al-Minhaj. Beirut: Dar al-Kutub al-'Ilmiyyah.

al-Zarqa. 2012. Syarh Al-Qawâ'id Al-Fiqhiyyah. Damaskus: Dâr al-Qalam.

Bakar, Abu. Ashal Al-Madarik. Beirut: Dar al-Fikr.

Dewi Sukma Kristianti. 2020. "Integrasi Prinsip Syariah Dalam Fungsi Intermediasi Lembaga Keuangan Syariah." Undang: Jurnal Hukum 3(2).

Febrian, Awaludin dan Andis. 2020. "Kedudukan Fatwa DSN-MUI Dalam Transaksi Keuangan Pada Lembaga Keuangan Syariah Di Indonesia." ALHURRIYAH : Jurnal Hukum Islam 6(2).

Hasanudin, Jaih Mubarok dan. 2017a. Fikih Mu'amalah Maliyyah; Akad Tabarru'. Bandung: Simbiosa. . 2017b. Fikih Mu'amalah Maliyyah: PrinsipPrinsip Perjanjian. Bandung: Simbiosa.

Hidayat, Enang. 2019. Kaidah Fikih Muamalah. Bandung: PT Remaja Rosdakarya.

Ibn Majah. 2008. Sunan Ibn Mâjah. Beirut: Dâr al-Fikr.

Ibn Najjar. 1999. Muntaha Al-Iradat. Beirut: Muasasah al-Risalah.

Ibn Nujaim. 1999. Al-Asybâh Wa Al-Nazhâir 'Alâ Madzhab Abî Hanifah Al-Nu'Mân. Beirut: Dar alKutub al-'Ilmiyyah.

Ilda Hayati. 2016. "Aplikasi Akad Tabarru' Wadi'ah Dan Qard Di Perbankan Syariah." Al Falah: Journal of Islamic Economics 1(2).

Maksum, Muhammad. 2014. "Model-Model Kontrak Dalam Produk Keuangan Syariah." AL- 'ADALAH XII(1).

Moh. Mufid. 2019. Kaidah Fikih Ekonomi Dan Keuangan Kontemporer: Pendekatan Tematis Dan Praktis. Jakarta: Kencana Prenada Media.

Muhamad Izazi Nurjaman dan Dena Ayu. 2021. "Eksistensi Kedudukan Fatwa DSN-MUI Terhadap Keberlangsungan Operasional Bisni Di Lembaga Keuangan Syariah." AL-IQTISHOD: Jurnal Pemikiran dan Penelitian Ekonomi Islam 9(2).

Muhammad Ash-Shiddiqy. 2018. "Analisis Akad Pembiayaan Qardh Dan Upaya Pengembalian Pinjaman Di Lembaga Keuangan Mikro Syariah.” Conference on Islamic Management, Accounting, and Economics (CIMAE) Proceeding. 1: 102.

Muhammad Shodiqi Ibn Ahmad Ibn Muhammad alBuruni Abu al-Harits al-Ghazi. 2003. Mausû'ah Al-Qawî̀id Al-Fiqhiyyah. Beirut: Muasasah alRisâlah.

Muslim. Shahîh Muslim. Beirut: Dar Ihya al-Turats al'Arabi.

Panji Adam. 2017. Fikih Muâmalah Mâliyah. Bandung: Refika Aditama.

Ramdhan, Athiyyah Adlan Athiyyah. 2007. Mausû'ah Al-Qawâ'id Al-Fiqhiyyah Al-Munadzamah 
Muhammad Yunus, Analisis Fatwa DSN-MUI terhadap Kontrak Akad Qardh Di Lembaga Keuangan Syariah (Studi Kasus pada BPRS Baiturridha Pusaka)

Lilmu'amalât Al-Mâliyyah Al-Islâmiyyah Wa Dauruha Fî Tawijîh Al-Nadzm Al-Mu'âshirah. Iskandariyyah: Dar al-Iman.

Wahbah al-Zuhaili. 2002. Al-Mu'âmalât Al-Mâliyyah Al-Mu'âhirah. Beirut: Dar al-Fikr.

Wiwik Hasbiyah. 2015. "Aplikasi Akad Tabarru' Dalam Lembaga Keuangan Syariah.” Jurnal Ilmiah Akuntansi 3(1): 548. 